$\underline{\text { ISSN 1466-1535 }}$

\title{
THE EUROPEAN POLICY REGARDING EDUCATION AND TRAINING: A
} CRITICAL ASSESSMENT

\section{SKOPE Research Paper No. 21 Autumn 2001}

By Jean-Luc Demeulemeester, UBL, Brussels and Denis Rochat, Université de Cergy-Pontoise 


\section{Editor's Foreword}

\section{SKOPE Publications}

This series publishes the work of the members and associates of SKOPE. A formal editorial process ensures that standards of quality and objectivity are maintained.

Orders for publications should be addressed to the SKOPE Secretary, SKOPE, Warwick Business School, University of Warwick, Coventry CV4 7AL. 


\begin{abstract}
In this paper we outline the (stated) philosophy governing the EU policy proposals regarding Education and Training (ET) systems. We review the various criticism that are addressed by the experts to ET systems as they are currently organised : in an age where knowledge and skills are of primary importance to maintain both individual and national competitivness, ET systems ignore the requirements of competitivness, partly because they are too heavily institutionalized (making therefore individuals less responsible), because they rely too much on formal accreditations and develop an elitist structure that drives the entire system away from market needs. The EU experts tend therefore to promote a new system more responsive to market needs, inter alia through the diffusion of information and transparency, the recognition of informal ways of learning, and a curricular content stressing much more methods (problemsolving abilities, information processing abilities....) than contents. The widespread use of ICT would play here a crucial role. The adaptiveness of ET systems could also be fostered by systematic evaluation and decentralization, while States, firms and individuals should increase their investement in human resources and capital. This lato sensu vocationalisation of ET systems would help in promoting social cohesion and a new sense of active citizenship. We review a series of criticism that could be levelled against such a policy agenda, which exaggerates the responsibiliy of the supply-side (the reform of ET systems would alone solve all of the problems) while downplaying the crucial importance of the demand side (the firms using the products of ET systems), and which probably overstates the benefits of a narrowly vocational ET system. The ideological preconceptions of the experts led them to exaggerate the ability of individuals to build their own curricula, and to neglect the role of teachers in education. Last but not least, they ignore the dangers linked with the introduction of shorttermism and commercial concerns in a world which was initially devised to prepare for the long run adaptiveness of society and individuals, not solely from an economic point of view, but also social, moral and political.
\end{abstract}




\section{Objectives}

The aim of this paper is to highlight the (stated $\left.{ }^{1}\right)$ philosophy governing the European policy regarding education and training systems. Education has become a new field of intervention of the EU, following the Treaty of Maastricht ${ }^{2}$ with articles 126 and 127 and the creation of a specific General-Division of the Commission, DG XXII (now labelled EAC, Education and Culture). It is indeed now thought that "we are moving towards a Learning Society, as a response to the emergence of the Information Society" (European Roundtable of Industrialists (1995), Education for Europeans. Towards the Learning Society, p. 8). This idea has been reasserted during the European Council held in Lisbonne in march 2000. In such a world, knowledge and skills are of primary importance in maintaining both individual and national competitive advantage. In other words, education and training, become key economic issues.

The legal basis of educational policy is organised by articles 126 and 127 of the Treaty of Maastricht. In article 126, one finds the statement of an objective: "the Community contributes to the development of an education of quality", without any definition of the latter term. Article $126 \$ 2$ gives some insights. One means in order to achieve the objective of quality would be the development of the European dimension in education, inter alia through the teaching of the languages of the member States and favouring the increased mobility of both students and teachers. Such a mobility also implies measures ensuring the academic recognition of diplomas all over Europe. Another dimension stated in the Treaty of Maastricht, besides mobility, is the promotion of cooperation between educational establishments, as well as the development of exchange of information and experiences on issues common to the education systems of the member States. Besides the two latter elements, the action of the Community should be directed towards the development of distance education. One should keep in mind that the EU actions should take account of the subsidiarity principle. It is indeed explicitly stated in $\S 1$ of both articles 126 and 127 that "the Community wishes to contribute in the development of quality education by encouraging cooperation between the member States and, if necessary, by supporting and completing their action while fully respecting the responsibility of the member States in the contents of education and in the educational systems organisation, just as much as their cultural and linguistic differences".

Besides this rather general legal basis, the EU experts and officials have expressed their general views either through official publications as the so-called White Paper on Education and Training: "Teaching and Learning. Towards the Learning Society" (1995)3, or through less official (although influential) publications such as the Report to the General Commissioners P. Flynn and E. Cresson carried out by the Study Group, comprising 25 experts led by J.L. Reiffers (Accomplishing Europe through Education and training. A Report of the Study Group, 19964), or the Proceedings of the International Conference organized by the Groupe Ampère, supervized by the EU (Teaching, Learning, Information: Towards an Open Socratic

\footnotetext{
1 We are here mainly concerned with the critical assessment of the official discourse as it appeared in the texts.

2 The text can be found on the internet: see http://europa.eu.int/abc/obj/treaties/en/entoc05.htm

3 White Paper, 1995, hereafter. The full english version can be downloaded from: http://europa.eu.int/en/record/white/edu9511/index.htm

4 Report, 1996, hereafter. The English version is available on the Net under the title: "Accomplishing Europe Through Education and Training"

The address is the following: http//www.europa.eu.int/en/com/dg22/reflex/en/en1.doc
} 
School, 1997)5. If the most recent contributions tend to stress more specific issues as the promotion of Infomation and Communication Technologies (ICT) ("Designing Tomorrow's Education: Promoting Innovation with new Technologies", Report from the Commission to the Council and the European Parliament, 2000) or international cooperation in education and training (Reichert and Wächter, 2000), there are exceptions as the Commission Staff Working Paper A Memorandum on Lifelong Learning (2000). EU officials are also influenced by lobbying groups as the ERT (European Round Table of Industrialists), and its research centre, IRDAC (the Industrial Research and Development Advisory Committee ${ }^{6}$ ).

In this article, we outline the ideas put forward in these documents and discuss their internal logic. We begin the paper (section II) with a summary of the perspective of European institutions concerning the dangers allegedly faced by the EU, and of the responsibility of Education and Training institutions. In section III, we present the type of evolutions advocated by the EU, and in section IV we subject them to a critical review. The last section $(\mathrm{V})$ is devoted to some concluding remarks.

\section{The issue at hand}

\section{II.1. Lack of competitiveness of the EU economy}

The EU officials or experts point to a severe and potentially dangerous competitiveness problem of the EU exports vis-à-vis America, Japan, and the NIC's. Competitiveness has now become a key objective of the European construction, as is illustrated by its adjunction to the list of the objectives to be pursued by the EU in the Treaty of Amsterdam (1997) ${ }^{7}$. The EU stresses this problem in a dynamic perspective, stressing the increasing pressure that currently low developped economies may exert in a near future on European economies, and foremost on their labour markets ${ }^{8}$. Many countries could indeed offer unskilled but also increasingly skilled manpower at a very low cost when compared to Europe (see the Report, 1996)- hence the requirement of fostering the quality dimension of goods 9 . The competitiveness issue is not analysed very deeply in the European reports published by the DG XXII, as it is a topic mainly dealt with by another General Division, the DG III «Industry ». The competitiveness issue, i.e. an external problem, is implicitly related to internal problems, more specifically to a deficiency in the working of its labour markets. This deficiency reflects itself not solely in the

\footnotetext{
5 We also refer to the Report carried out by the DG III (Industry), entitled Competitiveness of European Industry (La competivite de l'industrie europeenne, french version), Luxemburg, 1997.

6 For example, the Report of the Study Group (1996) makes explicit references to the IRDAC's latest reports (see The Report, 1996, § 66), as well as the White Paper (e.g. "the report from the European Roundtable of Industrialists (february 1995) stressed the need for flexible training with a broad knowledge base, advocating a 'learning to learn' approach throughout life", White Paper, 1995, p. 10-net).

7 The EU should aim at a «very high degree of economic competitiveness» (article 2, treaty of Amsterdam). See J.C. Tournier (1999), Mieux comprendre le Traite d'Amsterdam, Paris, ed. Eoletions Organisaiton.

8 When one focuses on current EU competitiveness problems, one is struck by the apparently good performance of EU current accounts, which appear increasingly positive (both in terms of goods and services ; the ratio X/M of the EU-15 amounted 144\% in 1999, following Eurostat), much more than the Japanese ones and, of course, the (negative) American ones. The problems lie much more in a bad orientation of exports (less emphasis on growing markets as China, South-East Asia, Latin America than other OECD countries) and in a bad specialization of exports (comparative disadvantage in terms of computers, electronics ; other sectors like telecommunications where if the current account is positive, the results are inferior to the OECD average). See also the deteriorating trade balance in high technology goods stressed by the DG Research (see table 9 in DG Recherche, Vers un espace européen de la recherche, 2000, p. 41). The most recent EU publications stress a more structural competitiveness problem due to a lack of dynamism, a slow adaptiveness regarding the transition from unskilled, low-spec activities to hightech,high-skill activities as ICT, heterogeneity within the European Union, insufficient productivity, lack of entrepreneurial spirit and slowness of business reaction (see Better, but not yet the best. Enterprise Policy Action to Improve Europe's Competitiveness, Commission Staff Working Paper, 2000, p. 7). Moreover, the global research effort of the EU seems to be insufficient (1.8\%, total R\&D spending in \% of GDP) when compared with the US $(2.8 \%)$ or Japan $(2.9 \%)$, the same being true for the number of researchers (not to speak of the reduced number of students in science and engineering, see DG Research, Vers un espace européen de la recherche, 2000, p. 21).

9 "These competitors will always have lower absolute costs and usually, after correcting for productivity differences, also lower unit labour costs. The consequence for a high wage country is to compete in quality" (DG Entreprise, Karl Aiginger, 2000, p. 1).
} 
international economy but also at home through severe unemployment (particularly among youngsters). The causes are essentially similar. On the one hand, labour markets are seen as very institutionalized. Wages cannot adjust in order to clear the market, partly because of regulations and impediments to free competition due to the role of trade-unions. On the other hand, there is a problem of quality in the supply of skilled manpower, due to deficiencies in the education and training system. The consequences are that EU exports suffer from excessive labour costs and that the products cannot respond to new demands because of bottlenecks in the supply of skilled manpower. The solutions to these two problems lie, according to the EU, in the deregulation of labour markets and in a reform of the Education and Training systems. It has nevertheless to be pointed out that the deregulation of labour markets is not considered by the EU experts of DG III (for example) as the key solution to all the problems. For example, (un)employment is argued to depend mainly upon more general economic performance. They even confess that short run flexibility might jeopardize long-run flexibility, by reducing the cohesion of firms (through reduced trust and less effective communication between members of the firm and the fuzzy organization which can result from excessive turnover and constant reorganisations). However, deregulation might help firms in adapting themselves more rapidly (see the Report on European Industrial Competitiveness, DG III, Luxemburg, 1997). As stressed hereabove, the last publications of the DG Enterprise (as Aiginger, 2000) stress now much more the quality dimension as a rational response to high labour costs. Education becomes therefore a central issue as there exists a direct link between the level of human capital and the quality of goods produced (see Gabszewicz and Turini, 2000, for a theoretical analysis). The Memorandum on Lifelong Learning (2000, p. 12) stresses therefore a key objective: "visibly raise levels of investment in human resources in order to place priority on Europe's most important asset-its people" ("Key message 2: more investment in human resources").

\section{2. The responsibility of education systems}

For the EU experts of the DG XXII, we are now moving towards a knowledge-based economy, i.e. an economy where national (on the markets abroad) and even individual (on the labour markets) competitiveness relies more and more intensively on the human capital held by the individual actors (workers, firms). It is not the accumulation of knowledge per se that is important, its stock is growing more than ever, and mastery of it is illusory, but rather the ability to learn quickly and to use the acquired knowledge productively. "Employers are increasingly demanding the ability to learn and acquire new skills rapidly and to adapt to new challenges and situations" (Memorandum, 2000, p. 11). "The White Paper acknowledges that investment in skills is a prime factor in competitiveness and employability" (White Paper, 1995, p. 73). Unfortunately, the EU experts point to several deficiencies of ET systems and address very severe criticisms against the current organization of ET systems:

\section{II.2.1 The ET systems ignore the requirements of competitiveness}

The current education and training (ET) systems appear much too conservative and are still characterized by a culture largely cut off from the world of the enterprise. "In the context of profound socio-economc changes, a conservative system will find it dfficult to produce innovative individuals" (The Report, 1996, §66, p. 23). Moreover, "ET systems are insufficently aware of the constraints of competitiveness" (The Report, 1996, p. vii). It is only "in adapting to the characteristics of future-oriented enterprise [that] education and training 
systems could contribute to European competitiveness and to the maintenance of employment" (The Report, 1996, p. vii).

\section{II.2.2 ET systems are too heavily institutionalized}

The institutionalization of ET systems ${ }^{10}$ poses a set of problems, essentially linked with the implied lack of flexibility and adaptiveness in a world where skill requirements are constantly changing. EU experts around the DG XXII believe indeed that competitiveness and growth will be favoured if capital (including human capital) can be produced and allocated where it pays off the most as rapidly as possible. Any hindrance to the mobility of human capital is an hindrance to economic performance. The current level of institutionalization of ET systems ${ }^{11}$ has now become an impediment to growth.

\section{II.2.2.a. The ET systems rely too heavily on formal accreditations}

Formal credentials such as degrees are viewed as a disincentive to further acquisistion of knowledge (as they are an "acquired advantage" and do not take the obsolescence phenomena into account). They do not promote risk-taking behaviour as large European organizations (large firms, administrations) often tend to link wage schedules with degrees obtained ${ }^{12}$ (as well as with experiences, i.e. years worked with the same employer). Such a system bases compensation on early acquisition of degrees but not at all for on the job performance. The latter element is stressed by the EU experts of DG III working on competitiveness. They stress that if the degrees help in making the labour market more transparent, they also encourage formal learning early in life, while rendering the access to qualification much more difficult later in life. This might both reduce the chances of unemployed workers to find another job by updating their skills, and reduce the chances of employers to find rapidly the skills they urgently need ${ }^{13}$. Moreover, the cross-sectoral and cross-national mobility is reduced by the low transferability of degrees both from one country to another and from an educational sector to another ${ }^{14}$. Finally, degrees are sometimes used as entrance requirement for an occupation. It might sometimes be in accordance with the public interest (as is the case with Medical degrees), but sometimes also only serve the sole interests of a profession (reducing competition $)^{15}$.

\section{II.2.2.b The ET systems develop an elitist structure that drives the entire system away from economic needs}

European ET systems are generally characterized by an elitist, pyramidal structure. Their main objective is to filter out an executive elite, a class of managers, professors, lawyers, engineers through a rather long and (initially) largely general and non vocational education. This heavily

\footnotetext{
10 I.e. its standardized organization mainly controlled by the State, with a set of regulations specifying the normal schooling career, and a system of degrees in order to verify whether a specified level has been attained.

11 Through a learning process which takes place within formal organizations (schools, universities), and along very formal procedures (examinations, degrees, prescribed times for obtaining such or such qualifications).

12 See for example the White Paper (1995), pp. 33-34.

13 EC (1997), Report on the European Industrial Competitiveness, Luxemburg, p. 95

14 The European State-membres have taken real initiatives inorder to close the gap. Following the 800th annversary of the foundation of the Sorbonne University (25 may 1998), four countries decided to go ahead and to launch a joint declaration concerning the harmonisation of European higher education systems. This initiative led to the Joint Declaration on a European Space of Higher Education, signed on the 19 June 1999 in Bologna by the representatives of 29 countries (besides the European Union and even the European Economic Space: Switzerland, Baltic countries, Bulgary, Czech Republic, Slovakia, Rumania, Hungary and Malta). See Chantal Kaufmann, 2000, pp. 158-160. The text of the Bologna Declaration can be found on the following website: http://www.snesup.fr/international/int99/int $99-$ bologne(f).htm

15 EC (1997), Report on the Competitiveness of European Industry, Luxemburg, p. 95
} 
selected elite gaining access to the top positions in society also enjoys the highest income. A large share of the student population hopes to become part of this elite, with the consequence that too large a share of the student population follows a very general educational path with few connections with the economy. If they fail to survive in this long and arduous "elitist track" they either drop out and try to find employment with no solid vocational training, or follow a vocational or technical education which is brought into disrepute as a failure track. The consequences are threefold: an elite too academically oriented and "not truly representative of the available human resource potential16" (White Paper, 1995, p. 33) and an excessively large share of students following general orientations instead of more technical or vocational ones (see The Report, 1996, §74, p. 26), with no prestige associated with the latter ${ }^{17}$. Moreover, "a number of recent surveys... show that over a long period the more elitist types of training are more often than not the prerogative of the upper managerial or intellectual strata" (White Paper, 1995, p. 34).

\section{II.2.2.c. The ET systems make individuals less responsible through their sequential organisation}

In the current organization students follow too standardized curricula along a prespecified order. The current ET system has a sequential structure, leaving no room for students to build freely their own competencies. They have few opportunities to build their own education project during most of their compulsory education and relatively few afterwards. They have to follow a rigid, predetermined fixed curriculum according to a fixed agenda. This system does not allow them to carefully address the cost-benefit aspects of their choices, both in terms of orientations and length of studies. There are few areas where crucial decisions have to be made, with long lasting and irrevertible effects. Students are therefore often trapped in certain educational paths with no opportunity to switch to other ones ${ }^{18}$. Moreover, some educational paths are dead end streets, impeding any return to higher or further education. This can lead to huge personal and social waste.

Altogether the EU experts reproach the current ET system for being cut off from the world of enterprise and for tending to value the knowledge accumulation per se, without much concern for economic usefulness.

\section{Towards a new educational system}

The ideal new system advocated by EU experts reflects the criticisms exposed above; it is defined by its promise to correct the majority of the aforementioned shortcomings.

\footnotetext{
16 "It could be considered that society 'locks out' in this way much talent which is frequently unconventional but innovatory, and that therefore it produces an elite which is not truly representative..." (White Paper, 1995, p. 33).

17 "This situation raises problems for the attractiveness of vocational education, which in several Member States is considered as a 'second best' option offering limited career prospects. Young people therefore tend to go for general education at the risk of feeling overqualified in their jobs". (White Paper, 1995, p. 33).

18 This is the more true since when free to make themselves human capital investment decisions, the students (or their families) are not accustomed to such choices, and are often confused by the variety of options opened to them. This opacity often leads parents of low-income families in particular to take the wrong decisions due to a lack of information or risk-aversion (see De Meulemeester and Rochat, 2001).
} 


\section{III.1 An ET system more responsive to the market needs through more information and transparency}

EU experts consider that a good educational system is one where any formation is open to everybody wanting and being able to acquire it. They want to render the existing ET system more open by simply making the whole structure more transparent through diffusion of information among prospective students. This policy might help the students in avoiding irresponsible and non motivated choices, as is often the case in higher education today. "Once the [cognitive] basics have been secured, two conditions would appear to be necessary if individuals are to be able to exercise responsibility in building up their abilities: adequate information and guidance; access to training along with all the opportunities available for mobility" (White Paper, 1995, pp.35). The Memorandum on Lifelong Learning (2000) puts forward as "key message 5" ("rethinking guidance and counselling") a clear objective: "ensure that everyone can access good quality information and advice about learning opportunities throughout Europe and throughout their lives" (Memorandum, 2000, p. 16).

\section{III.2 An ET system that recognizes informal ways of learning in order to promote lifelong learning}

EU experts believe that a good ET system should be less centered around the acquisition of degrees (even if they do not advocate its suppression, see White Paper, 1995, p. 3419; The Report, 1996, §108, p. 42) and that it should give real chances (and incentives) for informal acquisition of skills and abilities to be recognized. Greater external efficiency could be attained by giving less emphasis on formal degrees and accumulation of knowledge and more emphasis to informal learning and experiences. This objective could be met, inter alia, through the setting up of a system of personal cards of skills and competencies, where all validated fundamental, technical or vocational competencies would be reported (nowithstanding the way these competencies have been acquired, see White Paper, 1995, p. 3920). "The broad majority of Study Group Members support the necessity to develop the kind of systems described in this second approach, which returns a measure of initiative to the responsibility of the individual, in enabling each person -no matter where or when- to try as often as she or he wishes to secure accreditation for partial competencies, howsoever these have been acquired (whether through the formal education and training systems, through self-directed learning with the aid of IT, or through a range of informal means such as universités populaires or knowledge exchange networks" (The Report, 1996, §108, p. 42). The latter system should also ease the search process for both prospective employees and employers, thank to the use of IT technologies.

\section{III.3 Improving the quality of ET systems products: towards a new curriculum?}

The willingness of EU experts to improve the quality of the educational products is reflected in their concern for curricular reform and for a global reorganization of ET systems. On the one hand, the nature of the curriculum should be made more relevant to the needs of the economy by stressing problem-solving ability rather than mere knowledge accumulation and developing

\footnotetext{
19 "This is not, of course, to say that the paper qualification is not a valid route. The substantial efforts made by the Member states, and supported by the Community through SOCRATES and LEONARDO to strengthen initial training must of course be pursued. But in parallel with this, we need to make the best use of skills and abilities, irrespective of how they were obtained and to enhance everyone's potential by catering more closely for the needs of the individual, business and industry" (White Paper, 1995, p. 15-net).

20 "In the learning society individuals must be able to have their basic, technical and occupational skills validated, and how they were acquired. There are already instances of this: the driving licence, English (TEFL) and maths (Kangaroo test). A personal skills card providing a record of skills and knowledge accredited in this way should be availbale to all those who want one" (White Paper, 1995, p. 19-net).
} 
the ability of learning to learn (autonomy) rather than merely learning contents (see The Report, 1996, executive summary, p. viii). This should be eased by a systematic use of information technology (as the computer and other new information technologies). This could help the teacher in his task, and simultaneously give more weight to personal initiative of the students during the learning process. The new system should foster the autonomy of the student in order to achieve a real "pedagogy of innovation" (White Paper, 1995, p. 29). While the world of learning should be closer to the values of entrepreneurship and the world of economy (this was the second objective stated in the White Paper, 1995, pp. 60-63), a solid knowledge basis in sciences and mathematics (see the White Paper, 1995, p. 28), arts and humanities (see the White Paper, 1995, p. 30) should also be imperatively cultivated. The main idea is that such a new curriculum, instilling problem-solving abilities ${ }^{21}$, general cultivation $^{22}$ and innovation abilities ${ }^{23}$ should provide the workers with competitive advantages allowing them to survive in an ever-changing economy. The Lisbon European Council (march 2000) defined the "basic skills" in this sense as "IT skills, foreign languages, technological culture, entrepreneurship and social skills" (Memorandum on Lifelong Learning, 2000, p. 10). Some recent documents from the EC also stress the necessity of fostering enterpreneurial spirit at school "as it is generally weak across Europe as a whole" (see the Commission Staff Working Paper Better but not yet the Best. Enterprise policy action to improve Europe's competitiveness, Brussels, 9 november 2000, p. 8: "for if Europe still seems to believe that entrepreneurs are born, not taught, Luxembourg has taken steps to introduce notions of business in primary schooling").

\section{III.4 Improving the adaptiveness of ET systems through decentralization and evaluation}

The overall organization of ET systems could be made more adaptive and more responsive to the needs of society by increasing the degree of autonomy of and the degree of competition between schools. "Experience has shown that the most decentralised systems are also the most flexible, the quickest to adapt and hence have the greatest propensity to develop new forms of social partnership" (White Paper, 1995, p. 48, 26-net). "In Member States whose systems are more decentralised or allow more competition among educational establishments, or where private sector education is more developed, it is already more natural to respond to users' needs. The clear danger is that this will encourage an educational elitism which benefits those able to pay; children with special needs end up in state-run schools of inferior quality" (The Report, 1996, §178, p. 78).

Moreover, evaluation procedures should be encouraged (see EU dimension below). "The evaluation is indispensable, as it provides key pieces of information allowing the questioning of accepted practices. However, evaluation has a second and equally important function. Publicly accessible, comprehensible and well-founded evaluation provides a clear picture of the types of education and training available. This greater transparency is necessary so that users know what they are doing when they choose a particular field, establishment or training course. Thus, sound evaluation will greatly improve the average productivity of the education and training systems, since the learner can exercise free choice" (The Report, 1996, §190, p. $83)$.

\footnotetext{
21 The Report, 1996, executive summary, p. viii: "the capacity to resolve problems is, today, the decisive capacity which enables individuals to adapt to the contemporary fast-moving world, as well as favouring the development of enterprises".

22 "the development of a broad knowledge base, namely the ability to grasp the meaning of things, to comprehend and to make judgements, is the first factor in adapting to economic and labour market change", White Paper, 1995, p. 27, 10-net.

23 The Report, 1996, §93, p. 33.
} 


\section{III.5 Increasing the levels of investment in human resources at all levels}

EU experts, but also the conclusions of the Lisbon European Council (march 2000), point out the necessity of raising levels of investment in human resources (see Memorandum, 2000, key message 2, p. 12). "This means not only that current investment levels are regarded as too low to ensure the replenishment of the skills pool, but that it is necessary to re-think what counts as investment altogether" (see Memorandum, 2000, p. 12).

\section{III.5. a Inducing firms to increase their investments in training}

EU experts are conscious that there exists a kind of market failure as far as investment in training is concerned ${ }^{24}$. Moreover, other forces such as financial constraints or the excess of overqualified youngsters on the labour market market may lead to little incentive for firms to train their own employees, particularly if they are old or less qualified (White Paper, 1995, p. 37). "The overall training effort remains too modest" (White Paper, 1995, p. 37, 18-net). Therefore, in order to favour training within firms, the EU experts suggest a favourable fiscal treatment and incentives for firms employing high skilled employees in large proportions. "The approach to be explored is how to consider know-how and skills acquired by employees during the course of their duties as adding value to the company, so that part of the expenditure on training and salaries during the training period can be considered as depreciable intangible fixed assets and transferred accordingly on the balance sheet" (White Paper, 1995, p. 73, 51-net).

\section{III.5.b. Inducing individuals to update their skills (lifelong learning)}

EU experts consider that the first condition for lifelong learning lies in the individuals themselves: "people will only plan for consistent learning activities throughout their lives if they want to learn. They will not want to continue to learn if their experiences of learning in early life have been unsuccessful and personally negative. They will not want to carry on if appropriate learning opportunities are not practically accessible... And they will not want to invest time, effort and money in further learning if the knowledge, skills and expertise they have already acquired are not recognised in tangible ways, whether for personal reasons or for getting ahead at work" (Memorandum, 2000, p. 8). Besides these elements, "incentive measures must be more fully developed" (Memorandum, 2000, p. 12), e.g. through "individual learning accounts" ("encouraging people to contribute to the cost of their own learning through special savings and deposits that attract matching or supplementary grants or benefits from public or private funding sources", Memorandum, 2000, p. 12) or schemes allowing them to combine work with learning activities.

\section{III.6 Increasing the funding in order to ensure a successful reform}

It is also clear that such a deep reorganization of ET systems will require important financial means, and that an increase of the current levels of public funding seems unavoidable -at least in relative terms, in order to achieve ratios of public spending on ET systems in the GDP a little bit higher - 8\%- than the US (see White Paper, 1995, p. 48; The Report, 1996, §178, p. $78, \S 199$, p. 87).

24 This is the well known problem of poaching externalities, analysed inter alia by Margaret Stevens (1996), "Transferable training and poaching externalities", in: Booth, A.L. and D.J. Snower (eds), Acquiring Skills. Market Failures, their Symptoms and Policy Responses, Cambridge, Cambridge University press, pp. 19-40. 


\section{III.7 The EU as a pertinent level of intervention for comparing and evaluating the ET systems}

In order to achieve such a curriculum and organizational reform of ET systems, EU experts think that the European level is a very relevant level of decision (even if subsidiarity principles require that the real implementation should be left to the states or regions of the EU). The EU has indeed a broad view across all the experiences all over Europe, and it can compare them in order to identify the most successful experiments and suggest to apply them elsewhere. For example, it is well known that the German training system performs better in order to reduce youth unemployment ${ }^{25}$ than the more traditional French system (see The Report, 1996, §199, p. 87). Evaluation procedures should also be encouraged by the EU, in order to foster the overall efficiency of the system and improving the average productivity of ET systems (The Report, 1996, §189 to 192, p. 83).

The authorities at the European level could also play a significant role in the homogeneization of degrees and training schemes all over Europe (see the EC (1997) Report on the Competitiveness of European Industry, Luxemburg, p. 96). For the experts of DG III, « it is increasingly important that employers can more rapidly and more easily understand the meaning of different qualifications. It would be good to set up methods in order to make the qualifications more transparent in order to improve both the efficiency and the flexibility » (see the EC (1997) Report on the Competitiveness of European Industry, Luxemburg, p. 96).

\section{III.8 Promoting a system that brings benefits to the whole society}

\section{III.8.1 Enabling individuals besides employability}

The new educational system should not solely promote economic and technical competencies. The objective is not to transform people into mere robots but into autonomous, entrepreneurial actors ("educating citizens, not robots", see ERT, 1995, Education for Europeans. Towards the Learning Society, p. 15). "The main aim of education is to help each individual to fulfill his/her own potential, and to become a complete human being, not a tool for the economy" (White Paper, 1995, p. 27). Solid foundations in numeracy and literacy, and beyond that in sciences (see White Paper, 1995, p. 28) and arts and humanities -particularly history and history of sciences- (see White Paper, 1995, p. 30), should therefore be provided.

\section{III.8.2 Creating a new citizenship}

This education could also be the cornerstone of a new sense of European citizenship. It should foster the European feeling through the awareness of the shared heritage of the European civilization. But this new citizenship should also be an active, participative, one. In this sense, the new, active citizenship is not merely an issue of values; it is also a question of methods (The Report, 1996, §57, p. 19). In this respect, the EU experts suggest that the very same pedagogical tools that are used to foster information processing and problem solving abilities (i.e. economically useful abilities) should also help in creating more civic attitudes. Creating an European citizenship (i.e. an active, participative one) should be considered as a task very complementary to the one seeking to foster individual competitiveness through increased productive skills. "Labour market competitiveness can therefore be enhanced by encouraging

25 On this specific topic, see The Report, 1996, §103, p. 37. For other references to the German model (considered as more open to upward mobility within firms) see $\S 78$, p. 28 and $\$ 79$ p. 29. 
a well-developed sense of citizenship" (The Report, 1996, §57, p. 20), as "both employability and active citizenship are dependent upon having adequate and up-to-date knowledge and skills to take part in and make a contribution to economic and social life" (Memorandum, 2000, p. 5).

\section{III.8.3 Fostering social cohesion}

Another clear objective of the educational reforms, explicitly stated in the White Paper, is to increase social cohesion On the one hand, increasing individual competitiveness through a better education (as described above) should help people in preserving their social status in an increasingly competitive world. On the other hand, the educational system, by allowing for upward social mobility, plays a key role in social stability: "All European countries have affirmed these principles, which are at the heart of the contract that exists between our societies and their education and training systems. These principles legitimate both the formation of elites and make the corresponding existence of less advantageous social positions acceptable. A serious and permanent dysfunction at this level would without doubt be a significant obstacle to European development, including its economic development" (The Report, 1996, §121, p. 46).

\section{III.9 Coping with the requirements of a new economy}

The main aim is to make the whole system more responsive to market needs and more flexible and adaptive. The system should deliver the economy with the right quantity of people with the right skills as rapidly as possible, in order to cope with the changing demands of the economy. Briefly stated, the strategy put forward by EU experts is twofold: improving the quality of the products of ET systems as well as the speed of the production process, and simultaneously creating incentives for firms to invest in training.

\section{A critical assessment}

The arguments put forward by EU experts to advocate a reform of ET systems are not always convincing because of a lack of explicit connection with the major objective stated, i.e. restoring EU competitiveness. On the one hand the means of practical implementation of the wishes expressed is not clearly elaborated. This may be linked with the broad coverage of their analysis and its ambition to encompass all levels of education as well as training. On the other hand, the experts are not always explicit about the link between the problems they stress and the relatively imprecise solutions they suggest. This might be due to the institutional division between on the one hand DG XXII (now EAC), specialized in education and training issues, and the DG III (now Enterprise) focusing inter alia on the competitiveness of the European industry ${ }^{26}$. There may also be some internal conflicts within the DG XXII itself, resulting in some ambiguity in the published reports. One can infer from the published documents ${ }^{27}$ that what EU experts believe is that education should evolve in parallel with the changes observed in the economy and the world of the enterprise. Time has become increasingly important in defining competitiveness in the world economy, and to produce just in time what the consumer demands is now a real imperative (Sennett, 1998; see also the documents published by the European Table of Industrialists [ERT], as Education for Europeans. Towards the Learning

26 See for example the Report by DG III on The Competitiveness of European Industry (1997).

27 As well as from documents of lobbying groups as the ERT, see below. 
Society, 1995: "industry has had to respond quickly in order to remain competitive", p. 9). In such a world ET systems should not constitute a form of bottleneck.

\section{IV.1 A too superficial diagnosis concerning the current organization of ET systems}

EU experts tend to consider that the current organization of ET systems as a potential hindrance to the enhancement of European competitiveness. Therefore the ET system should be made more vocational on its lower ends, and more technological and scientific on its higher levels (shortage of scientists and engineers) in terms of contents taught. It should also promote autonomy, information-processing and problem-solving abilities. It should narrowly serve the economy even if EU experts also contend that developing such abilities may also promote a new active citizenship and increase the probability of avoiding unemployment.

\section{IV.2 Is there a real problem with the supply of human capital?}

Such a view may be too simplisitc. On the one hand, it assumes that ET systems systematically do not respond adequately to the new demands of human capital emanating from the economy. Recent analyses (Manacorda and Petrongolo, 1999) tend to suggest that if there seems to be a "clear sign of a net relative demand shift towards skilled labour in Britain, France, Germany, Italy, Spain and the United States" (p. 188) ${ }^{28}$ during the last two decades (idea of a skill-biased technological change, see Juhn et al., 1993), the extent to which this evolution of relative demand for skills may not be matched by a parallel increase in the relative supply varies from country to country. If the problem of skill mismatch may be serious in the USA or UK, but not in continental Europe where "skill mismatch did not cause serious labour market problems, where wage differentials did not widen and the bulk of the rise in unemployment could not be blamed on an unbalanced evolution of the demand and supply of skills", Manacorda and Petrongolo, 1999, p. 203). It is true that both the European countries as well as the European Commission often stress a lack of graduates in science and technology (for example, the DG Research stressed that in Germany there was an halving in the number of physics students since 1991; see DG Research, 2000, p. 21). But there is no proof against the idea that this movement away from sciences would be a rational response to declining market signals relative to, say, law, business or economics (even if this situation might be harmful for long-term growth potential). More generally one can regret the absence of econometric or modelled approaches supporting the arguments put forward by experts from DG XXII.

\section{IV.3 The EU approach neglects the importance of the demand side}

EU experts have a very clear supply-side perspective, i.e. they locate the source of the competitiveness problem mainly in the inadequate supply of human capital. Briefly stated, the European economy suffers from a shortage of qualified workers. It is implicitly assumed that once ET systems have been reformed, the new graduates will be hired and correctly used by the firms, contributing to the production of quality (high-tech), and hence competitive goods. There is little interrogation ${ }^{29}$ regarding the demand-side of the market. The often quoted shortage of engineers and scientists may for example be linked with the lack of market incentives due to a relatively lower demand for their services, as compared with lawyers and

28 "Evidence of this shift is represented by changes in the skill distribution of unemployment and/or in wage differentials. Australia, Canada, Netherlands, Sweden and Norway seem in fact to have kept the imbalance between the demand and supply of skills to a relatively steady level over the last two decades" (Manacorda and Petrongolo, 1999, p. 188).

29 One is the advantageous fiscal treatment which should be given to the human resources of the firms. 
financial analysts ${ }^{30}$. The view of the experts is mechanical in the sense that the problem is narrowly located in ET systems and not in the overall organization of the economy. This piecemeal approach may be misleading, as some recent economic historical or socio-economic analyses have pointed out (Fox and Guagnini, 1993; Ashton and Green, 1996; Sanderson, 1999).

The experts of DG XXII tend to believe that by simply increasing the level of human capital of the European population, private enterprise will automatically make further use of it. This very classical belief that the supply will create its own demand can be very misleading (see Sanderson, 1999). An economy can indeed be competitive by producing low quality products with low skilled workers. If such a strategy has proven successful in the past, it is very difficult to change the behaviour of employers (see the analyses of Finegold and Soskice, 1988, on lowskill/low-wage equilibria), even if experts contend that it might be dangerous in the future. Only a sharp drop in profitability might convince employers to change strategy, and not merely the availability of high skilled workers. The latter will simply be under-employed, as the example of many LDC's suggests.

It must be pointed out that EU experts from DG III are more cautious than those of DG XXII, and that if they recognize that ET systems can certainly contribute to the development of a qualifed and adaptive workforce, the key factor in ensuring high levels of productivity and competitiveness is the way those competencies produced are used. It is also clear for them that the latter element cannot be influenced solely through reforming ET systems (see the Report on European Industrial Competiveness, 1997, pp. 95-96).

\section{IV.4 The EU experts overstate the benefits of a narrowly vocational ET system}

On the other hand, this approach stressing a vocationalization of ET systems in terms of the nature of the courses may lose sight of some important dimensions of education, even from the narrow economic viewpoint. Fostering information processing and problem solving abilities, coupled with the disregard for the general, liberal arts curriculum, means fostering technical abilities rather than broader capacities of judgement, self criticism and distanciation from narrow technical details. Briefly stated, it seems that EU experts stress what the current system mainly lack, i.e. technical education for workers. They do not point out that managers and leaders should also receive a broader education, less directly vocational, providing them with analytical and synthetical abilities, besides mere technical knowledge ${ }^{31}$. This is important for people having to manage complex systems and take very rapid decisions within a fuzzy and uncertain context (Morin, 1999). The EU experts also disregard the importance of a broader education for the average worker: some authors (Streeck, 1992) have indeed stressed the importance of such an education to foster adaptiveness of people and ability to learn. More generally, it seems difficult to advocate an active citizenship without stressing at the same time a broader notion of the role of education.

30 See on this topic Vishny, Murphy and Shleifer, 1991.

31 The sometimes skeptical view on the value of the traditional, humanistic curriculum may be linked with its elitist flavour, something that some experts, influenced by the so-called "modernist ideology" of the French 1968 thinkers, dislike very much. On these arguments see Le Goff (1999). 


\section{IV.5 The EU experts exaggerate the ability of the individual to build his own curriculum}

The EU experts also want to complement the existing educational system (and its accreditation system based upon nation-based degrees) with a new one based upon informal on-the-job learning or even self-learning (accreditation through a personal card of skills and competencies). The former should be fostered in order to ensure the command of a solid knowledge (math, sciences, languages), while the latter should be the locus of more vocational learning.

The new system also wants to emphasize the role of personal responsibility, in order to ensure a greater flexibility. As employees live in a very competitive world, they know that in order for them to survive, they have to constantly take the best decisions both in terms of career orientation and learning of skills. In their liberal philosophy, no state agency could take better decisions than individuals in situ, who possess the most relevant information for the problem at hand. The overall efficiency of the system is held to be guaranteed by the fact that people will face the cost of their decision if they fail. Even if it is contended that ET opportunities will be open to everybody, and that information will be made available to everybody, it remains that people are in fact unequal as far as information processing abilities are concerned (not to speak of the attitudes towards risk, see Mingat and Eicher, 1982 or De Meulemeester and Rochat, 2001). People coming from less advantaged social backgrounds often lack the relevant information or do not know how to treat it and translate it into purposive decisions (see Boudon, 1973 ; see also Wilkinson, 1996, for related considerations concerning the link between health and inequalities). Nothing in the proposed reorganization of ET systems seems capable of counteracting this.

\section{IV.6 The EU experts tend to neglect the key role of teachers in education}

The EU experts advocate a reform of the curriculum intended to give people informationprocessing and problem-solving abilities. They do not give any precise advice beyond that general statement, with the exception of suggesting a widespread use of information technology (see for example the Report from the Commission to the Council and the European Parliament: Designing Tomorrow's Education. Promoting Innovation with New Technologies, Brussels, 27 january 2000). In this sense they appear quite attached to the belief that techniques by themselves might solve all the problems, so that educational processes will become more efficient just by introducing more physical capital (i.e. computers) complementary to the existing human capital (i.e. teachers).

More generally, EU experts seem to rely more on physical capital than on human capital, except the one of the (learning) individual, in the learning process. They stress the role of the free individual, they advocate the widespread use of information technology to liberate the people from the role of the teachers. "Teaching as a professional role faces decisive changes in the coming decades: teachers and trainers become guides, mentors and mediators. Their roleand it is a crucially important one-is to help and support learners who, as far as possible, take charge of their own learning" (Memorandum, 2000, p. 14). This approach, again reflecting some anti-authoritarian stance of 68 thinkers, may be misleading. As often pointed out in the literature, there are role models who play also a key role in the development of the personality of the young learners (let alone the problem of motivation) (see the survey by Haveman and Wolfe, 1995). 


\section{IV.7 Is Europe the most appropriate and effective locus of decision in a globalized economy?}

Besides this very "free-market" view, one can question the implicit assumption that the European level would be the most appropriate level of decision (or, at least, of initiative).

\section{IV.7.a Europe is too heterogenous an entity}

On the one hand, it is very difficult to admit the idea that the EU level could identify the best practices only by making international comparisons, the latter being sufficient to secure their implementation everywhere else. Europe is indeed still a very heterogeneous set of countries and a succesful experiment in a given context of economic development, but also of cultural attitudes, will not necessarily prove successful in a completely different environment (see Scharpf, 1999).

\section{IV.7.b The role of policy in a globalized environment}

On a more fundamental level, there seems to be an internal contradiction between the idea that the EU should promote the competitiveness through a reform of education. Reforming education is simply reforming the process that leads to a supply of skills, of human capital. Nothing guarantees that the latter will be compatible with the demands expressed by firms. These demands are indeed determined by the nature of the products they produce and sell (high tech, low tech). In a free-market economy the latter decisions are left to profitmaximizing firms and should not be induced by the State. And even if the European level would like, for example, to promote the production and exports of high tech products, it would be difficult to implement this in the context of as firms which are now increasingly transnational. The "nationalist" interventionist perspective of the EU experts is contradictory with the universal conception of free-marketeers, for which the nations become obsolete concepts in a unified global economy.

\section{Concluding remarks}

The policy that the EU experts would like to see implemented is the corollary of their philosophical views regarding the optimal organization of society. They are partisans of a freetrade and a laisser-faire economy -hence the accent they place on the benefits linked with the participation of Europe in the world-economy, without any protective barriers. The material benefits linked with this choice are held to far outweigh the (inter alia) social costs. This argument is for them decisive, because they are utilitarian and consider the (material) social welfare (intimately coupled with the competitiveness) of the majority as the only goal that policy-makers should be allowed to pursue. However, participating in a free market requires considerable reforms in order to secure competitiveness. These reforms aim at fostering individual responsibility (as liberalism is mainly an individualistic philosophy) and flexibility (the society will be prosperous only if it allows for continuous change). This leads the EU reformers in a very interventionist attitude towards existing educational institutions in order, if not to dismantle them, at least to complement them with new systems, much more flexible and less rigidly institutionalized. They want to make the overall ET system structure much more responsive to market needs. In this sense, they consider the latter just as a tool in promoting material welfare and competitiveness. In this way, they introduce short-termism and commercial concerns in a world which was initially devised to prepare for the long run adaptiveness of society and individuals, not solely from an economic point of view, but also 
social, moral and political. The judgement made of such a program heavily relies upon the faith one has in the idea that social welfare is just equal to the material welfare ${ }^{32}$ and that the best way to promote it is linked with the maintenance and the development of a free trade and laisser faire society, where the sum of the (short-run) decisions taken by interest-maximizing individuals always leads to the best of all the worlds possible, and where by consequence policy-makers only ensure the greatest flexibility by partly removing or at least decreasing the importance of many institutions. As this judgement heavily relies upon one's philosophical preconceptions, one can question the neutral basis on which these policy recommendations are based.

32 One could indeed at least be skeptical concerning the relevance of methodological individualism in order to assess well-being. Inequality per se may matter (importance of relative deprivation, see Wilkinson, 1996). 


\section{REFERENCES}

Ashton, D. and F. Green (1996), Education, Training and the Global Economy, Cheltenham, Edward Elgar.

Boudon, R. (1973), L'Inégalité des chances. La mobilité sociale dans les sociétés industrielles, Paris, éd. Armand Colin.

De Meulemeester, J.L. and D. Rochat (2001), Rational Choice under Unequal Constraints: The Example of Belgian Higher Education, Economics of Education Review, forthcoming.

Commission of the European Communities (1995), White Paper on Education and Training: Teaching and Learning: Towards the Learning Society, DG V and XXII, Luxemburg.

Commission of the European Communities (1996), Accomplishing Europe through Education and Training, Luxemburg.

Commission of the European Communities (1997), Report on the Competitiveness of European Industry, Luxemburg.

Commission of the European Communities (2000), Better but not yet the Best. Enterprise Policy Action to improve Europe's Competitiveness, Commission Staff Working Paper, Brussels, 9 november 2000.

Commission of the European Communities (2000), Vers un espace européen de la recherche, Luxembourg.

Commission of the European Communities (2000), A Memorandum on Lifelong Learning, Brussels, 30 october 2000.

Commission of the European Communities, Karl Aiginger (2000), Europe's Position in Quality Competition: Background Report for the "European Competitiveness Report 2000", DG Entreprise (Enterprise Policy), Luxembourg.

European Roundtable of Industrialists (1995), Education for Europeans. Towards the Learning Society, Brussels.

Finegold, D. and D. Soskice (1988), "The Failure of Training in Britain: Analysis and Prescription", Oxford Review of Economic Policy 4(3), pp. 21-53.

Fox, R. and A. Guagnini (eds) (1993), Education, Technology and Industrial Performance in Europe, Cambridge, Cambridge University Press.

Gabszewicz, J.-J. et A. Turrini (2000), "Workers' Skills, Product Quality and Industry Equilibrium", International Journal of Industrial Organization, 18(4), pp. 575-593. 
Haveman, R. and B. Wolfe (1995), "The Determinants of Children's Attainments: A Review of Methods and Findings", Journal of Economic Literature 33(4), pp. 829-1878.

Juhn, C., Murphy, K. et B. Pierce (1993), "Wage Inequality and the Rise in Returns to Skill", Journal of Political Economy, 101, pp. 410-442.

Le Goff, J.P. (1999), La barbarie douce. La modernisation aveugle des entreprises et de l'école, Paris, La Découverte (Sur le vif).

Manacorda, M. and B. Petrongolo (1999), "Skill Mismatch and Unemployment in OECD Countries", Economica, 66, pp. 181-207.

Mingat, A. and Eicher, J.C. (1982), Higher education and employment markets in France, Higher Education 11, pp. 211-220.

Morin, E. (1999), La tête bien faite. Repenser la réforme. Réformer la pensée, Paris, Seuil (l'Histoire Immédiate).

Sanderson, M. (1999), Education and Economic Decline in Britain, 1870 to the 1990s, Cambridge, Cambridge University Press (New Studies in Economic and Social History).

Scharpf, F. (1999), Governing in Europe, Effective and Democratic, Oxford, Oxford University Press.

Sennett, R. (1998), The Corrosion of Character. The Personal Consequences of Work in the New Capitalism, New-York and London, Norton.

Stevens, M. (1996), "Transferable Training and Poaching Externalities", in: A.L. Booth and D.J. Snower (eds), Acquiring Skills. Market Failures, their Symptoms and Policy Responses, Cambridge, Cambridge University Press and CEPR.

Streeck, W. (1992), Social Institutions and Economic Performance. Studies of Industrial Relations in Advanced Economies, London, Sage Publications.

Tournier, J.C. (1999), Mieux comprendre le Traite d'Amsterdam, Paris, Editions d'Organisation.

Wilkinson, R.G. (1996), Unhealthy Societies. The Afflictions of Inequality, London and New-York, Routledge. 